\title{
Featured Artists - Interview with Featured Artist, Diana Tso, Toronto, January, 2017
}

\section{专访艺术家 Diana}

\author{
Stephen K. Levine \\ The European Graduate School, Switzerland
}

\begin{abstract}
Diana Tso is a Chinese-Canadian writer, actor and storyteller, who recently produced her play, Comfort, in Toronto, Canada. Comfort deals with the situations of Chinese women who were forced into sexual slavery by the Japanese army during World War Two. The horrific story of these women's experience is held by the play's beautiful music and song, based on the Chinese opera Butterfly Lovers and sung in Chinese, and by the expressive movement of the actors. When I saw the play in December 2016, I was moved not only by the story but also by the aesthetic power of the presentation. To my mind, it gave a partial answer to the question of how we can make art out of trauma.

After the performance, I went up to Diana and asked if she would be willing to talk about the play for the readers of this journal. The following dialogue is an edited version of our conversation, held in Toronto in January, 2017.
\end{abstract}

Keywords: Comfort, a play about comfort women in China in WWII, Chinese opera, violence against women, trauma, art

\section{摘要}

Diana Tso 是一位加拿大华裔作家，演员和故事讲述者，最近在加拿大多伦多出品了她 的演奏"慰安"。作品关于在二战期间被日本军队强迫性奴役的中国女性的情况。这些女 性经历的可怕故事源自中国歌剧"梁祝"这一中国乐曲演员表演舞蹈，以戏剧美秒的音乐 和歌曲为主。当我在2016年12月看到该戏剧时，我不仅受到故事的影响，还受到演讲 的审美力量的影响。在我看来，这部分回答了我们如何通过艺术摆脱创伤的问题。

演出结束后，我找到黛安娜，问她是否愿意为这本期刊的读者讲述这个戏。以下对话是 我们在2017年1月在多伦多进行的对话的编辑版本。

\section{关键词: 慰安妇，二战，中国戏剧，创伤，艺术，妇女暴力}

Stephen K. Levine (SKL): Before we talk about your play, Comfort, I'd like to ask you about your background. Perhaps you could tell us about the way that you came to theatre and the influences that brought you to this kind of work.

Diana Tso (DT): When I went to the University of Toronto, I was studying literature at the time and most of my friends were in the business program, taking courses like accounting. They wanted to start a theatre collective for to preserve and celebrate our 
heritage. They were predominantly of Filipino heritage but they asked me to join them because I was in the arts. They had a play and a director but it didn't work out, so we decided to write a play together. I was into the arts, so they asked me to direct it. I had to be like a duck and just dive in and swim. It was very successful and, because they were in business, they knew how to get the financing to do it. Nobody in the company was paid, but the venue was paid for and they organized getting actors for the auditions and the rehearsal space. That was a positive experience and, as a result, I thought I should learn to be a better director. I was actually working full-time in Accounts Receivables while I was finishing my fourth-year university, but it was really boring. I was rehearsing at night and that was such a fun experience that I thought I would get more involved in theatre. I ended up auditioning for a show at the Tarragon theatre in Toronto the Farm Show by Paul Thompson - which had a diverse cast. I became the assistant director instead of being in it. I wanted to explore acting to become a better director. I thought acting would allow me to step into other people's shoes to understand their perspective and to learn more fully how to communicate with them but I kept getting director jobs. I still wanted to act and, for SummerWorks theatre festival, I tried out for a play called Worlds Between.

It was part Chinese opera, part contemporary Western theatre. The opera was The Legend of the White Snake. It was exciting because it was part of my own culture as a Chinese person. I was learning acting techniques and getting to know my cultural heritage through performing that I never experienced before.

SKL: How did you come to do Comfort?

DT: In 1996 I saw a documentary called, In the Name of the Emperor. Before that, I never knew that there was another forgotten holocaust in World War II. I decided I needed to talk about this because part of history - the Nanjing massacre - was being

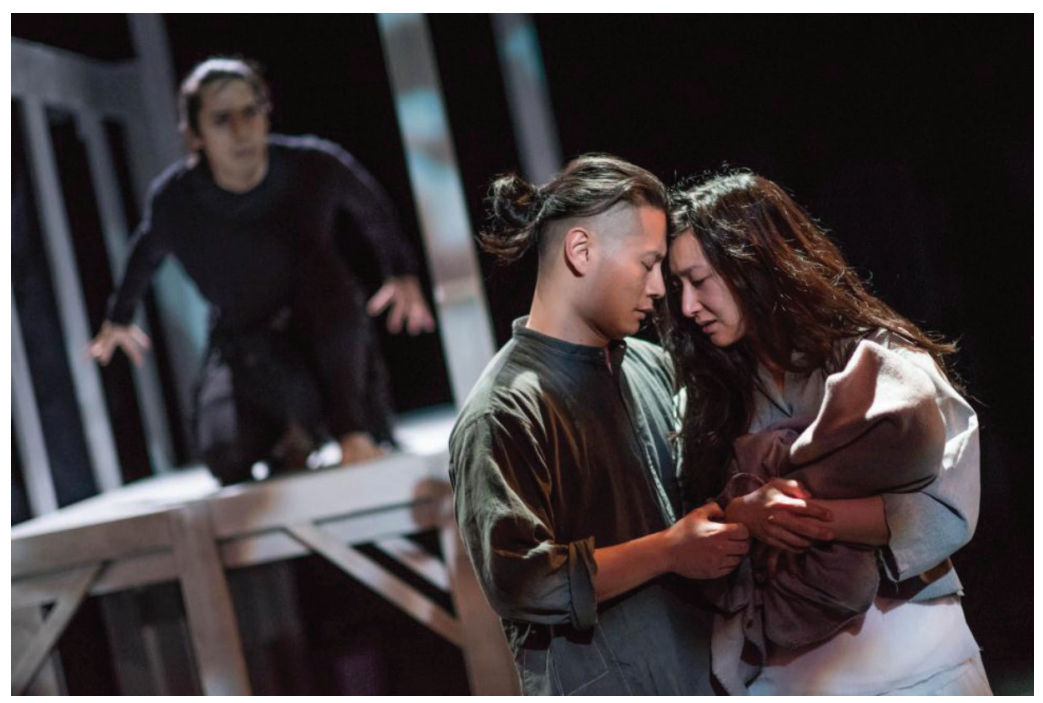

FIGURE 1 | Vicki Kim. Jeff Yung. Oliver Koomsatira by Dahlia Katz 


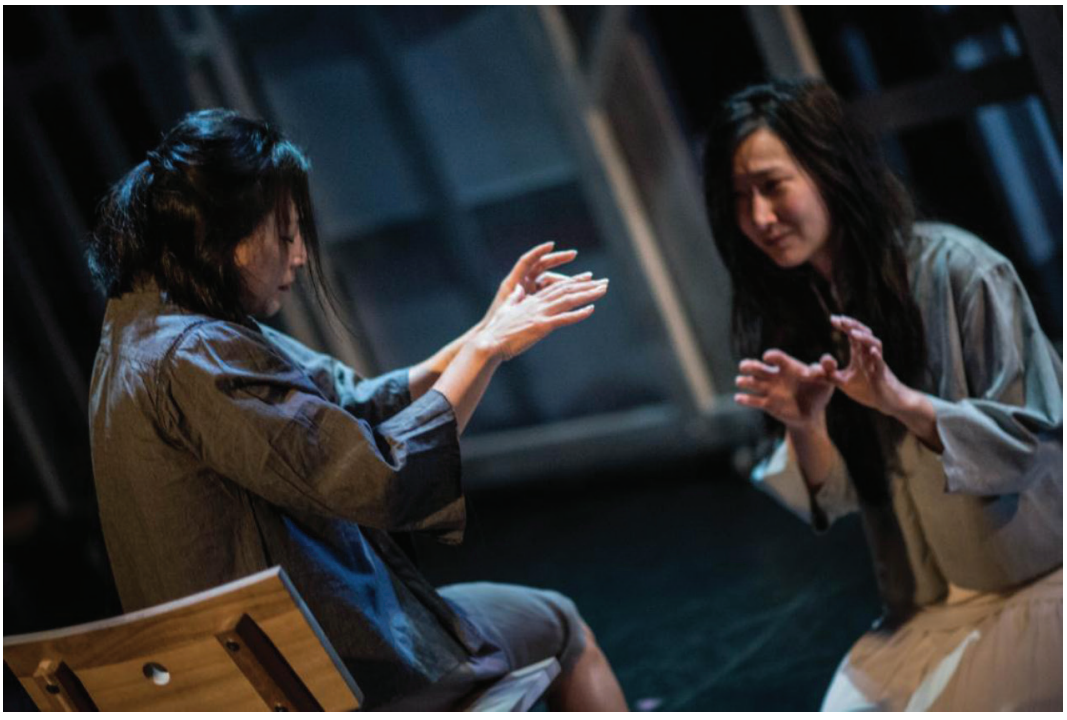

FIGURE 2 | Jen Hum.Vicki Kim by Dahlia Katz

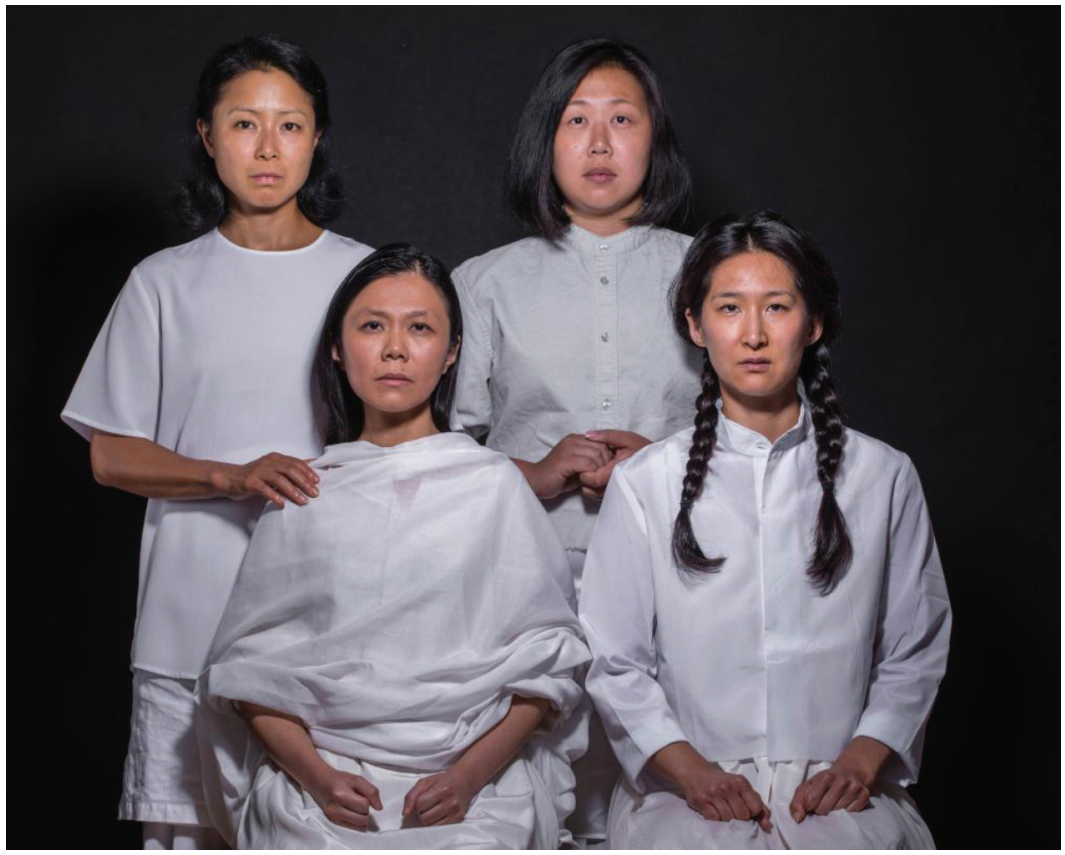

FIGURE 3 | Phoebe Hu, Jen Hum, Vania Chan, Vicki Kim, by Dahlia Katz

silenced,. The first play I wrote was Red Snow. It was about a granddaughter searching for her grandmother's side of the story of what had happened in Nanjing. As a young girl, the grandmother had fallen in love with a man who shared her passion for the Chinese opera, The Peony Pavilion, which was a story about how the power of love could resurrect the dead. During the World War he was forced to witness her being 

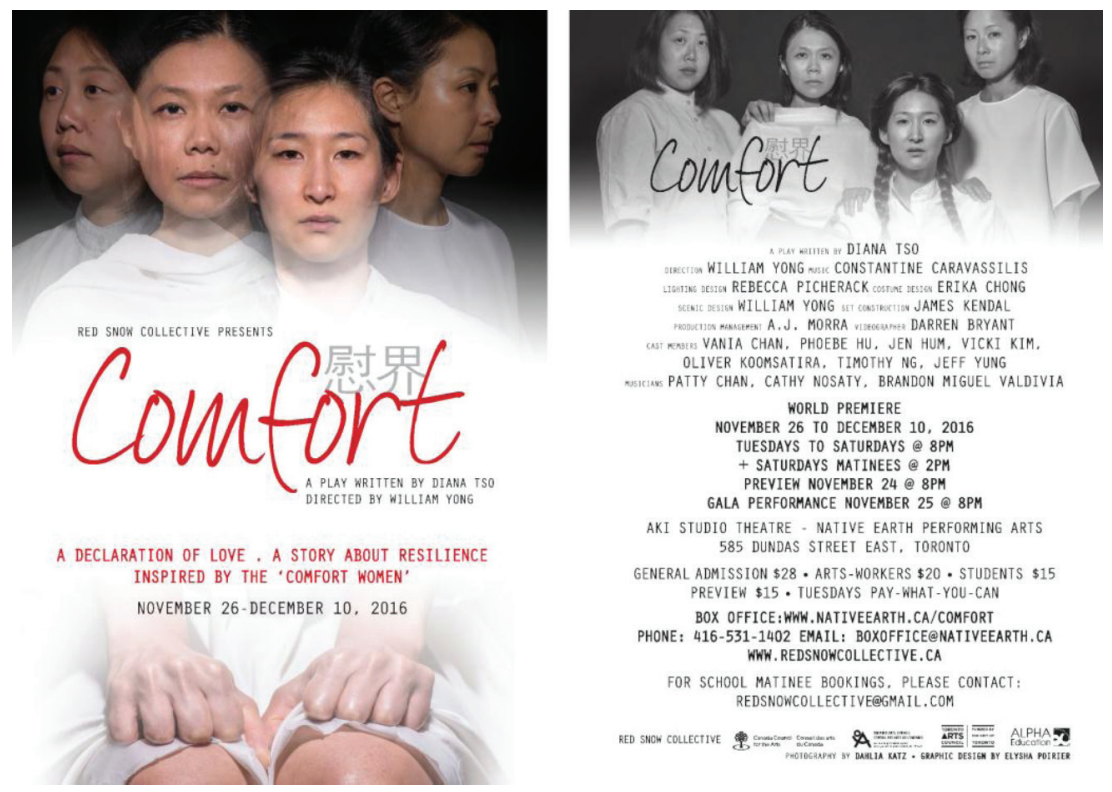

FIGURE 4 | Comfort poster by Elysha Poirier and photo by Dahlia Katz

gang-raped and killed. He never sang again from that day on - not until his granddaughter returned from China with a Japanese man she'd met while searching for her grandmother in Nanjing.

That same year I got a grant to write another play about love and war. I asked myself, what else did I want to say about that after Red Snow? With the new play, I thought, what if this woman was not murdered and had to survive as a "comfort woman"? That was in 2014, a year after I got the grant. I realized that these women's stories had still not surfaced because the women were dispersed across China and the rest of Asia. A lot of people thought that the only comfort women were Korean, because the Korean women had a higher profile from the early 1990s - coming together in solidarity to protest in front of the Japanese embassy in Seoul, Korea. Many Chinese comfort women didn't have the same opportunity to get together since they were so dispersed. Also, many were too ashamed to speak about it and testify. I decided I would write about their story.

In Comfort, I focused primarily on the Chinese women, with one Korean comfort woman living in the house. It's also a story about a young couple who fall in love through their shared passion for the Chinese opera The Butterfly Lovers - an opera which focuses on the transformative power of love. One of the women is separated from her love and is imprisoned in a comfort house for eight years. The reason why I use opera in my work is because it goes to the roots of my Chinese heritage and represents transcendence through love and art. That's how I came up with writing Comfort as a love story. A lot of my writing - especially when it comes to tragedy - I express through poetry. My work uses the heightened language of poetry and also involves a strong movement base. I think that comes from my background, having studied for two years 
at the Ecole Jacques Lecoq, a school of physical theatre in Paris. Lecoq taught us that sometimes movement can speak more forcefully than words. I don't like to write in a naturalistic way all the time. Using poetry and movement gives another dimension to my expression as a storyteller. Even though I'm writing a play or telling a story, I use a lot of poetry and movement to heighten the expression.

SKL: I'd like you to talk about the Chinese influence on your work and how your own cultural heritage comes into it.

DT: I love Chinese opera, the mythology and the ancient stories that survive in it. They speak about the power of love and show the transformation that comes through art. Despite all the tragedies that happen in this world, I still believe that love is the only way. I think you have to hang onto that hope in order to move forward and in order for humanity to move forward and to be better at creating a home and an earth where there's harmony between people.

SKL: Can you talk about your personal relationship to your Chinese heritage?

DT: I was born in Ottawa, Canada, and my parents are from Hong Kong. They both grew up there, but my father was born in Shanghai during the war. He was living in the French concession so it was safe there, but every time his mother sent him out to get rice or anything else he was constantly bullied by the soldiers who were actually only teenagers themselves. When I was writing my first play, Red Snow, my father had recurring nightmares of fighting off the soldiers again. It was a kind of trauma that returned years later. My mom was also very young at that time; she remembers being on her father's shoulders, collecting money for the war effort to fight against the Japanese.

My parents came to Canada in the 60's and lived in Montreal. They got married in Montreal and I was conceived there. I guess that accounts for the whole French romantic path I'm on. My mom got a job as a director of social work at Wellesley Hospital in Toronto and so we moved here. I basically grew up in Toronto.

SKL: Did you grow up with a sense of Chinese culture around you?

DT: Yes, I did. I had to go to Chinese school every Saturday, which was a bit of a torture for me, but I was bribed by dim sum and kung fu movies so that really helped. I loved the movies and I love dim sum. Growing up as a Canadian but from a different heritage, you're always searching for your roots. I was proud and excited to find out more about my Chinese heritage. I am who I am through my roots - through my ancestry and my cultural heritage - but at the same time I've always celebrated the diversity around me in Toronto where there are so many communities and cultures. In my own family we have both Jewish and Irish family members. We also have English ones. It's beautiful and colorful - like the rain forest of Costa Rica. I think if we could celebrate this diversity, we'd have a better world.

SKL: What's your next project? 
DT: The next piece that I'm working on is called The Monkey Queen's Journey to the East, in which the Monkey Queen travels from Canada to China. It's inspired by the $16^{\text {th }}$ century, nine-volume novel of the Monkey King in Wu Cheng'en's The Journey to the West, but I'm taking it from a female perspective. The Monkey Queen has been invented. I gave birth to her.

SKL: One of the themes of Comfort is sexual abuse of women by men. Would you say that you're taking a particularly feminist perspective?

DT: I'm not sure I understand the question about the feminist perspective, but I am giving voice to women who are silenced - not only the comfort women but the women of today These include the missing aboriginal women in Canada that we still haven't done anything about. There's violence against women happening in our own country right outside our door. There's so much work to be done globally. This is a part of human history that needs a voice. Violence against women must be stopped. In Comfort, I'm also aware of contemporary perspectives on gender and class - not only the relationships between men and women but women's attempts to find their own identity. In the play, Dan Feng is attempting to go to school,but her parents are very much afraid that if she gets educated she won't get married and will be vulnerable. It's a conflict between the generations as well.

SKL: Let's talk about the music and movement in the play. I was very much affected by the choreography and the songs from Chinese opera. It seems to me that you wove together the lyrics and music of Chinese opera - and also the movement styles coming from Chinese opera - in a truly contemporary way. Can you talk about that?

DT: I actually started workshopping the play after my first draft, but instead of having a group of actors come in and analyze it from a textual and character perspectives, I hired musicians and the music composer with the director, so we analyzed the draft from the perspective of movement and music first.

Musicians are always glued to their instruments, so it was great for them to explore movement which they'd never done. They also vocalized; we went to a Toronto voice coach, Fides Krucker, who guided us in working with our voices and bodies. That was a new thing for the musicians, and I was happy that they slowly embraced that. Through movement, they would improvise music under the direction of the composer. Then they would compose something. All of a sudden a text would come into my mind.

For example, they created a piece of music and I envisioned the moon looking at the devastation of what he or she sees from above Shanghai, so I wrote a monologue for the Moon. Then they created another piece of music which sounded to me like running in the train station after a bombing and that became the music for Dan Feng running away from home. That was exciting because it was the music that was provoking me to write from the characters' point of view. I didn't feel it was dictated. I didn't say to myself, "Oh, I have to write a speech about the moon right here." It was just that the music evoked scenes and characters. After that year we auditioned actors and then we started working on the text together. Due to a limited budget, I could only incorporate the musicians with the music that we created in 2014 for a developmental workshop day in 
Spring 2015. I am grateful to all the arts councils (Toronto Arts Council, Ontario Arts Council and the Canada Council for the Arts) who supported the development and the production. We did have a public presentation - part reading, part movement, part live music - after Spring 2015 with the actors. It was great to dialogue with the audience afterwards and hear their responses to the play. We also had a public reading in August 2015 at OISE (Ontario Institute for Studies in Education) during events that commemorated the anniversary of World War Two in Asia. It was not until 2016 that we did the production of the play.

SKL: I'm interested in the reception of the play. Can you talk about that?

DT: We had public shows as well as school shows. The school shows were sold out. We received wonderful responses. One of the musicians who does a lot of young people's theatre said she had never seen high school students so quiet and focused before. We got also feedback from the teachers and that elicited a lot of conversation. It's a very sensitive topic because of the subject matter. The second half of the play - which is about the violence against women - left a lot of things to be discussed. I felt it might be hard for the students to absorb it, especially since it was not naturalistic theatre., but they loved the fact that it was done through the media of music and movement as opposed to having a more naturalistic text-based approach.

SKL: To me there's a strong difference in tone between the first and second act. In the first act, Dan Feng is trying to find her identity as an independent woman in a traditional society. There's a clear sense of aspiration and hope. In the second act, however, when she becomes a comfort woman her hopes are dashed and there is a great sense of despair and hopelessness. Did you feel that you had to have the lovers unite years later to bring some hope to the play? The lovers do seem to be reunited in the last scene, but I wasn't sure if that was a dream sequence or whether it was something that your characters actually experienced.

DT: They actually experienced it. They did get reunited at the end of the war and then the action jumps quickly to 30 years later, to when the baby (who was born by a rape from a Japanese soldier) appears as an adult who is being raised by both the protagonists. To me, this was a step towards forgiveness. All children are innocent. It's the birth of a life regardless of who the parents are. The child is now a grown man and, yes, he comes from two different cultures who were once enemies. I think you have to have hope, otherwise I would have no reason to write. If there is no hope in the world and no possibility for change, then we're at a dead end as a human race.

SKL: I'm wondering what effect being involved in this play has had on you personally.

DT: A lot of joy comes up when I'm seeing the words come to life through other artists. You're giving birth to the story, but it's a collective birth; it's how we have to come together as a society in order to make that change. I don't think one person can make that change alone; it's a collaboration. This process stands for working in solidarity - that's the most exciting thing for me. Every single interaction you have with an artist, a 
designer or even with an audience member (like how you and I met) the dialogue continues between us. What's important is how we get to keep that connection between human beings going and growing. That gives me a lot of hope and inspires me both as an actor and as an artist.

SKL: Do you feel that, after having written and produced this play, you have used the arts to work with the trauma of the comfort women and have come to some kind of peace with it?

DT: Yes, I do. When I took Red Snow, my previous play, to China, the audience was almost all people for whom it was not their first language. The play was in English with Chinese subtitles, but still they thought it was inspiring and a positive thing that this story was written - not just to speak the truth of what happened in history but to initiate healing. I know they still are waiting for an apology by the Japanese Government something which may never happen in their lifetimes - but the community has to start finding ways toward their own healing and their own closure by working together and sharing and speaking their stories.

SKL: Are you planning to go to China to present Comfort?

DT: I hope so, but in terms of festivals it's very hard because they don't really pay you anything, so it probably won't happen unless a producer there can pick up the show. I would love to see the play have a second life, but I just came out of it and am already starting to work on another piece. I'll be focused on acting this year, going away for seven months to Stratford, Ontario, so Comfort is going to be put on hiatus. Before I leave Toronto, however, I will be sending things to presenters who may be interested in remounting this work somewhere in Canada.

SKL: Is there anything else you'd like to talk about?

DT: There's actually a grant called the "Creative Engagement Grant to Stop Violence and Harassment against Women" which is given by the Ontario Arts Council. I applied for that before but was not successful. Now it's by invitation only, and they want me to apply again. I hope with that there'll be a remounting of Comfort, as well as many other stories that need to be told to stop violence against women.

SKL: Have your parents seen the play?

DT: Yes. Both of them. My mom said that she didn't even know about the comfort women during the war because she was very little. I think the war touched them in a personal way since they were part of it as kids. I remember that the particular showing of Comfort my parents came to - the same one you came to - was when I had a guest speaker, Joy Kogawa, speaking about her book, Gently to Nagasaki which touches on the massacre of Nanjing. She said that without going to Nanjing and navigating through it, she couldn't get to Nagasaki to confront that history. Joy is a fantastic human being and artist. When I was younger, one of my first shows was Naomi's Road, which was based on her experience in the Japanese internment camp in Canada. I had asked her to 
speak after the play as part of my "Share the Stage on the Same Road" series where I invite artists to share their work as women and give voice to their stories. Joy is always an inspiring and eloquent speaker, but after the performance of Comfort she could not speak; we just hugged each other and cried on the stage. Then she sat down, and I noticed that there were other actors there to hear Joy speak. I invited them up on stage to start a conversation with the audience. Of course, my mother raised her hand at some point - I knew my mother doesn't ask questions, she makes statements - she said how proud she was of me and how she had always instilled in me the wish to be proud of my history and heritage and that she was so glad that I am on this path, continuing to speak the stories. It was embarrassing, but I know it was all done out of love. One of the actor's parents had disowned her because she took the artist's way. There were some actors' parents who did not come to see the show because they didn't support their children being in the arts. I think that is a challenge for a lot of Asian artists, so I guess I'm very lucky that my parents came to my show - even though they embarrassed me by saying that they loved me. Basically, my mom said that love is the only way - then Joy started talking about love and how that is the message of the goddess of mercy and that we have to go on that track to find healing.

I feel very grateful that my parents are supportive. In the beginning my dad was not; he thought being an artist meant living in poverty. When I started, I just didn't know how I would survive - but it's been over 18 years, and I'm still doing it so that's a good thing. Thank goodness for my mom. She always says do what you love and be happy because life is too short!

SKL: Have you met any of the comfort women?

DT: Yes. In 2009 I had the precious opportunity to be with an organization called Alpha Education which takes educators across Canada to meet survivors of World War II in Asia and to learn more about that history. I went to China and Korea on their peace and reconciliation program. Unfortunately, the history that is taught in schools is very Eurocentric; Alpha brings another perspective to schools. I had the opportunity to meet the comfort women when I was at one of their Wednesday protests. They have one every Wednesday since the early 1990s in front of the Japanese embassy. I was out there with the grandmas. It was great standing in solidarity with them. It was a humbling experience just to meet comfort women survivors and to hear them speak and remember. Many of the survivors' memories are going; there's a lot that they are starting not to remember. In a way that's good, because what they do remember is so horrific. I think it's our responsibility now to remember for them. That's what I wanted to do with Comfort; to remember and to honor these resilient women, their stories, and their voices.

\section{About the Authors}

Stephen K. Levine, Ph. D., D.S.Sc., REAT, Dean of the Doctoral Program in Expressive Arts in the Division of Arts, Health and Society at The European Graduate School (Switzerland), Professor Emeritus at York University (Toronto). Email: stephen.levine@, egs.edu 
Diana Tso, theatre artist, actor, playwright, storyteller, poet, artist in education, University of Toronto in English Literature BA hons. (Toronto), Ecole Internationale de Théâtre de Jacques Lecoq (Paris, France), Red Snow and Comfort available at www. playwrightsguild.ca/playwrights, Website: www.redsnowcollective.ca, Email: redsnowcollective@gmail.com

\section{References}

Red Snow Collective website: http://www.redsnowcollective.ca/

Comfort Trailer \#1 by Darren Byrant https://youtu.be/lcCPzVrVKUA

Red Snow Collective's Comfort - Performance Excerpts 2 https://www.youtube.com/ watch? $\mathrm{v}=\mathrm{xmzZc} 3 \mathrm{riTUQ}$

Comfort, a video introduction by playwright Diana Tso https://www.youtube.com/watch?v=ucNe7-RH1ls

Red Snow Collective's Comfort - Performance Excerpts 1 https://www.youtube.com/ watch? $\mathrm{v}=\mathrm{CXimen} 5 \mathrm{RJ} 2 \mathrm{E}$

Comfort Video with Volcano's Emerging Artist Series by Aries Cheung https://youtu.be/ucNe7-RH1ls 